\title{
WIRAUSAHAWAN MAHASISWA DI PROVINSI ACEH: KENDALA DAN FAKTOR PENENTU KESUKSESAN
}

JULLIMURSYIDA

Dosen pada Fakultas Ekonomi dan Bisnis, Universitas Malikussaleh

The purpose of this study was to identify factors that contribute to the success of student entrepreneurs in Aceh from the aspect of the desire for achievement, locus of control, self-efficacy, instrumental readiness and subjectives norm. This research is quantitative research which applied the survey approach to be able to determine the success factors of entrepreneurs among students. The results indicates that the need for achievement, locus of control, self efficacy, instrumental readiness and subjectives norm can explain the interest of students to be entrepreneurs in Aceh. The results of this research will hopefully help to clarify aspects of the development of entrepreneurship among the students that will enrich their knowledge of entrepreneurship especially among the students in Indonesian. The result of this study will be able to take a step closer to finding ways to increase the number of students to become entrepreneurs.

\section{Keywords: Self-efficacy, Subjective Norms, Locus of Control, Need for Achievement, Instrumental Readiness}




\section{PENDAHULUAN}

Pada saat kemerosotan ekonomi seperti ini, kekhawatiran terhadap pekerjaan atau pengangguran menjadi topik yang hangat untuk didiskusikan. Terutama di Indonesia yang merupakan negara dengan jumlah penduduknya dikategorikan banyak. Pengangguran bukan hanya terjadi di lingkungan yang pendidikannya rendah, bahkan pengangguran terdidik juga menjadi suatu masalah besar di Indonesia. Rata-rata universitas di Indonesia baik univeristas negeri maupun universitas swasta menghasilakn lebih dari 100 ribu lulusan per tahun. Namun, di antara lulusan tersebut, pengangguran yang terjadi meningkat dari 183,629 pada tahun 2006 menjadi 409,890 pada tahun 2007. Ini adalah masalah besar sampai dengan sekarang.

Berwirausaha merupakan trobosan guna menanggulangi pengangguran terdidik. Mulai tahun 2009, kegiatan kemahasiswaan didorong untuk menyediakan pendidikan kewirausahaan kepada mahasiswa yang punya motivasi untuk berwirausaha. Sekitar 70\% dari dana yang diterima oleh setiap perguruan tinggi masuk dalam daftar isian pelaksanaan anggaran masing-masing perguruan tinggi, yang dialokasikan untuk mendukung mahasiswa dalam menjalankan bisnis (Kompas, 2011). Kelompok pengusaha yang signifikan secara ekonomi adalah lulusan universitas yang masih muda yang mampu mengakses pendidikan di seluruh dunia (Kovereid \& Isaksen, 2006; Nabi, Holden \& Walmsley, 2006). Para lulusan muda ini tidak hanya menghadapi berbagai pilihan yang berhubungan dengan keputusan karir di pemerintahan ataupun swasta tetapi mereka juga harus meningkatkan kesadaran kewirausahaan dan pekerjaan yang mandiri sebagai alternatif untuk karier (Morris, 2006; OECD, 2002; Wennekers, stel \& Thurik, 2005). Lulusan universitas adalah orang yang berkualitas dan jika mereka dipekerjakan, mereka bisa mengubah bakat mereka untuk hasil yang lebih baik. Lulusan universitas/ sarjana di negara-negara maju lebih mempertimbangkan untuk menjadi pengusaha yang mandiri dibandingkan orientasi kerja di perusahaan milik pemerintah atau swasta (Matlay, 2005; Nabi et al., 2006). Di Indonesia, angka penggangguran ter- didik cukup tinggi.

Berdasarkan data Biro Pusat Statistik (BPS), jumlah sarjana (S-I) sebanyak 409.900 orang pada tahun 2007. Di sisi lain, jumlah pengangguran terdidik bertambah 216.300 orang atau sekitar 626.200 orang pada tahun 2008. Dari jumlah tersebut, lulusan SMA menyumbang angka yang paling besar yaitu sebanyak 3.369.959 juta jiwa diikuti pengangguran SD sebanyak 2.179. 792 juta jiwa, SMP sebanyak 2.166.619 juta jiwa, diploma/akademi sebanyak 519.867 jiwa. Pada tahun 2009 bulan Februari, juga terjadi peningkatan pengangguran yaitu sebanyak 9.258.964 juta jiwa dari total angkatan kerja sekitar 113.744.408 juta jiwa. Masih berdasarkan data dari BPS, dari jumlah 9,25 juta jiwa penganggur tersebut sebagian besar ada di desa. Jika ditinjau dari latar belakang pendidikan, maka pengangguran yang tamatan SD kebawah sebanyak 2.508.253 juta jiwa, SLTP sebanyak 2.094.378 juta jiwa, SMA sebanyak 2.341.592 juta jiwa, sedangkan diploma sampai sarjana sebanyak 891.638 jiwa.

Wirausahawan di kalangan mahasiswa yang tumbuh menjadi menarik perhatian untuk diteliti. Literatur menunjukkan bahwa akses yang lebih baik untuk pendidikan telah menciptakan lulusan setiap tahunnya yang mengnggaur sehingga menciptakan tekanan ekonomi dalam penyediaaan lapangan kerja yg memadai (Matlay, 2005; Nabi et al., 2006). Dalam pasar global yang berfluktuasi terutama disebabkan oleh perampingan korporasi multinasional dan restrukturisasi dan strategi, menyebabkan banyak organisasi atau perusahaan mengurangi penyerapan tenaga kerja. Hasilnya adalah pengangguran yang tinggi di kalangan lulusan universitas (Matlay, 2005; Morris, 2006; Nabi et al., 2006; Wennekers et al, 2005).

Di Malaysia misalnya, hampir 99,2 persen, atau 546.218 perusahaan baik yang berskala kecil atau menengah yang mempekerjakan lebih dari setengah $(56,4 \%)$ dari angkatan kerja (SMIDEC, 2006). Sedangkan kebijakan publik terlihat pada sektor perusahaan menengah dan kecil (UKM) sebagai sumber yang layak untuk memberikan kesempatan kerja baru bagi lulusan pendidikan tinggi/sarjana (Nkongolo-Bakenda, Anderson \& Ito, 2004), Kendala yang sering dihadapi adalah bahwa mayoritas dari UKM adalah usaha mikro 
yang mungkin tidak mampu menampung lulusan universitas untuk bekerja sehingga tidak menjadi pilihan karir yang menarik bagi lulusan tersebut (Morris, 2006; Nabi et al., 2006). Oleh karena itu, penelitian ini dilakukan untuk mengidentifikasi faktor-faktor yang mendorong mahasiswa memilih untuk menjadi wirausaha dan faktor yang menjadi penentu kesuksesan bagi wirausahawan mahasiswa tersebut di Propinsi Aceh.

\section{TINJAUAN PUSTAKA}

\section{Kewirausahaan}

Kata entrepreneur berasal dari kata Prancis, entreprendre, yang berarti berusaha. Dalam bahasa Indonesia, "wiraswasta" berasal dari kata Wira yang memiliki arti utama, gagah, berani, luhur, teladan atau pejuang. Sedangkan swa berarti sendiri serta Sta yang memiliki arti berdiri. Sehingga wiraswasta (entrepreneur) dapat diartikan pejuang yang utama, gagah, luhur, berani dan layak menjadi teladan dalam bidang usaha dengan landasan berdiri diatas kaki sendiri. Tarmudji, 1996 mendefinisikan wirausaha sebagai suatu kemauan keras dalam melakukan kegiatan yang bermanfaat.

Menurut Zimmerer dan Scarborough (2002) kewirausahaan adalah seseorang yang menciptakan suatu bisnis baru dengan risiko dan ketidakpastian menuju keberhasilan laba dan pertumbuhan lebih lanjut dengan mengumpulkan sumber daya yang ada dan mengidentifikasi peluang. Suryana (2000) mendefinisikan kewirausahaan sebagai sifat, ciri dan watak seseorang yang memiliki kemauan dalam mewujudkan gagasan inovatif ke dalam dunia nyata secara kreatif. Di sisi lain Hisrich dan reda (2002) mendefinisikan kewirausahaan adalah sebagai suatu proses menciptakan sesuatu yang baru dengan nilai persembahan usaha dan waktu yang perlu serta memperoleh keuntungan dan mampu menghadapi risiko. Sedangkan Meredith et al (2002) mengatakan bahwa wirausaha adalah orang-orang yang mampu melihat dan menilai kesempatan bisnis, mengumpulkan sumber-sumber daya yang dibutuhkan guna mengambil keuntungan daripadanya dan mengambil tindakan yang tepat guna memastikan sukses.

\section{Karakteristik Kewirausahaan}

Scarborough dan Zimmerer (1993) mangemukakan delapan karakteristik kewirausahaan, yang meliputi: Preference for moderate risk, yaitu lebih memilih risiko yang moderat, artinya dia selalu menghindari resiko, baik yang terlalu rendah maupun terlalu tinggi. Desire for responsibility, yaitu memiliki rasa tangung jawab atas usaha-usaha yang dilakukannya. Seseorang yang memiliki rasa tanggung jawab akan selalu mawas diri Value of achievement over money, yaitu lebih menghargai prestasi dari pada uang. High level of energy, yaitu memiliki semangat dan kerja keras untuk mewujudkan keinginannya demi masa depan yang lebih baik. Confidence in their ability to success, yaitu percaya akan kemampuan dirinya untuk berhasil. Desire for immediate feedback, yaitu selalu menghendaki umpan balik yang segera. Skill at organizing, yaitu memiliki keterampilan dalam mengorganisasikan sumber daya untuk menciptakan nilai tambah.. Future orientation, yaitu berorientasi ke masa depan, perspektif, dan berwawasan jauh ke depan.

Secara ekplisit, Stainhoff dan Burgess (1993) mengemukakan beberapa karakteristik yang diperlukan untuk menjadi wirausaha yang berhasil, yaitu: Memiliki visi dan tujuan usaha yang jelas. Bersedia menanggung risiko waktu dan uang. Rencana, mengorganisir. Kerja keras sesuai dengan tingkat kepentingannya. Mengembangkan hubungan dengan pelanggan, pemasok, pekerja, dan yang lainnya. Bertanggung jawab terhadap keberhasilan dan kegagalan.

\section{Minat Berwirausaha}

Segala perbuatan manusia timbul karena dorongan dari dalam (faktor internal, push factor) dan rangsang dari luar (faktor eksternal, pull factor), tetapi tidak akan terjadi sesuatu jika tidak berminat. Secara umum minat adalah kecenderungan terhadap sesuatu (Noeng Muhadjir, 1992). Minat berdasarkan dari beberapa pendapat di atas adalah perasaan senang atau kecenderungan hati seseorang yang mengarahkan individu kepada suatu pilihan tertentu dengan berpartisipasi terhadap kegiatan yang menjadi obyek kesukaannya itu. Minat mempengaruhi proses dan hasil belajar seseorang sebab jika seseorang tersebut 
mempelajari sesuatu dengan penuh minat maka dapat diharapkan hasilnya akan lebih baik. Selain itu minat adalah "perasaan tertarik atau berkaitan pada suatu hal atau aktifitas tanpa ada menyuruh" (Tarmudji, 1991). Minat seseorang dapat diekspresikan melalui pernyataan yang menunjukkan seorang lebih tertarik pada suatu obyek lain.

Dapat pula dimanifestasikan melalui partisipasi dalam suatu aktivitas seseorang yang berminat terhadap sesuatu obyek tertentu cenderung menaruh perhatian lebih besar. Niat berwirausaha (entrepreneurial intention) dapat dilihat sebagai minat untuk menciptakan suatu organisasi baru atau sebagai perilaku mengambil resiko untuk memulai suatu bisnis baru ( Katz \& Gartner, 1988). Niat (intention) dapat dilihat seperti penyebab suatu tindakan dan yang lebih tinggi adalah melaksanakan tindakan, yang lebih tinggi lagi adalah kemungkinan dalam melibatkan aksi/tindakan (Chandrashekaran, et. al, 2000). Berdasarkan uraian diatas dapat dipahami bahwa kesadaran seseorang yang tertarik dan senang pada suatu usaha akan nampak dalam kegiatan mempelajari, memahami, dan berkecimpung dalam usaha itu. Aktivitas atau kegiatan yang dilandasi dengan minat kemungkinan besar akan berhasil, karena dilakukan dengan rasa senang dan tanpa paksaan. Kegiatan-kegiatan tersebut dilakukan untuk mencapai tujuan tertentu, yaitu untuk memenuhi kebutuhannya. Seseorang yang berminat terhadap wirausaha akan merasa senang atau suka melakukan berbagai tindakan yang berhubungan dengan wirausaha. Minat bersifat pribadi, sehingga minat individu antara satu dengan yang lainnya berbeda. Bahkan minat pada diri seseorang dapat berbeda dari waktu ke waktu, karena minat merupakan kesediaan jiwa yang sifatnya untuk menerima sesuatu dari luar individu. Maka minat sekaligus kaidah pokok dalam menanggapi sesuatu, termasuk di dalamnya minat mahasiswa untuk berwirausaha.

\section{Faktor-Faktor yang Mempengaruhi Minat Kewirausahaan}

Para ahli mengemukakan bahwa seseorang memiliki minat berwirausaha karena adanya motif tertentu, yaitu motif berprestasi (achievement motive). Menurut Suhanda (dalam Suryana, 2003) motif berprestasi ialah suatu nilai sosial yang me- nekankan pada hasrat untuk mencapai yang terbaik guna mencapai kepuasan secara pribadi.

Wirasasmita (1994) mengemukakan beberapa alasan mengapa seseorang berwirausaha, yaitu :

1. Alasan keuangan, yaitu untuk mencari nafkah, untuk menjadi kaya, untuk mencari pendapatan tambahan, sebagai jaminan stabilitas keuangan.

2. Alasan social, yaitu untuk memperoleh gengsi/ status, untuk dapat dikenal dan dihormati, untuk menjadi contoh bagi orang tua di desa, agar dapat bertemu dengan orang banyak.

3. Alasan pelayanan, yaitu untuk memberi pekerjaan pada masyarakat, untuk menatar masyarakat, untuk membantu perekonomian, demi masa depan anak-anak dan keluarga, untuk mendapat kesetiaan suami/istri, untuk membahagiakan orang tua.

4. Alasan pemenuhan diri, yaitu untuk menjadi atasan/ mandiri, untuk mencapai sesuatu yang diinginkan, untuk menghindari ketergnatungan pada orang lain, untuk menjadi lebih produktif, dan untuk menggunakan kemampuan diri.

Begley dan David (1980) menemukan lima dimensi yang menjadi faktor-faktor psikologi yang mempengaruhi kewirausahaan, yaitu:

1. Kebutuhan untuk berprestasi: Disini wirausahawan mempunyai kebutuhan untuk berpretasi (need for achievement) sangat tinggi.

2. Letak kendali: dimana individu mengendalikan hidup mereka sendiri, bukan keberuntungan atau nasib.

3. Toleransi terhadap risiko: wirausahawan yang bersedia mengambil risiko memperoleh hasil yang lebih besar daripada orang yang tidak mau ambil risiko.

4. Toleransi terhadap keragu-raguan. Disini tidak ada keraguan dalam mengambil sikap.

5. Tingkah laku tipe A: ambisius, energik.

Sementara, Ramayah dan Harun (2005) mengemukakan faktor-faktor yang mempengaruhi minat berwirausaha adalah:

1. Faktor demographics and individual background (latar belakang individu dan demografis) 
2. Faktor Personality traits (ciri kepribadian) yang terdiri dari:
a. Need for achievement (kebutuhan berpres- tasi)
b. Locus of control (tempat kendali)
c. Self efficacy (kepercayaan diri)

3. Faktor contextual elements (unsur-unsur termasuk/ tergantung) yang terdiri dari :

a. Instrumental readiness (kesiap-siagaan)

b. Subjective norms (norma-norma hubungan)

\section{METODE PENELITIAN}

Pendekatan yang digunakan untuk penelitian ini, baik untuk menjawab pertanyaan penelitian, pengumpulan data, analisis dan interpretasi hasil yaitu dengan menggunakan metode kuantitatif. Dimana pengumpulan datanya digunakan dengan metode survey.

\section{Pengumpulan Data}

Metode pengumpulan data dengan Penelitian ini dilakukan dengan menggunakan metode survey dalam pengumpulan data. Peneliti mengumpulkan data secara langsung dengan membagikan kuesioner untuk diisi oleh responden. Adapun instrumen (alat) penelitian yang digunakan untuk mengumpulkan data dan informasi adalah kuesioner, yang berisi daftar pertanyaan berdasarkan variabel yang diteliti. Adapun yang menjadi populasi dalam penelitian ini adalah jumlah seluruh mahasiswa yang berada pada universitas, baik negeri maupun swasta di propinsi Aceh yang telah memulai usaha minimal tiga tahun terakhir.

\section{Sample}

Sampel adalah kumpulan elemen yang sifatnya tidak menyeluruh melainkan hanya sebagian dari populasi saja. Hermawan (2006) mendefinisikan sampel sebagai suatu bagian (sub set) dari populasi, dengan mengambil sampel penulis menarik kesimpulan yang akan digeneralisasikan terhadap populasi. Jadi dalam penelitian ini sampel yang akan diambil adalah sebesar 15 dikalikan jumlah variabel dalam penelitian. Sehingga total sampel dalam penelitian ini minimal adalah 90, namun dalam penelitian ini akan mengambil sampel sebanyak 100 orang

\section{HASIL DAN PEMBAHASAN}

\section{Karakteristik Responden}

Karakteristik responden menggambarkan identitas responden dari usia, jenis kelamin, dan lamanya responden bekerja yang diperoleh dari 67 responden seperti yang dijelaskan pada Tabel $1 \mathrm{di}$ bawah ini:

Tabel 1

Karakteristik Responden

\begin{tabular}{|l|l|r|r|}
\hline \multicolumn{1}{|c|}{ Item } & \multicolumn{1}{c|}{ Kategori } & Freq. & Persentase \\
\hline Usia & <18 Tahun & 2 & 3,0 \\
& 18-23 Tahun & 51 & 76,1 \\
& >23 Tahun & 14 & 20,9 \\
\hline Jenis & Laki-laki & 45 & 67,2 \\
Kelamin & Wanita & 22 & 32,8 \\
\hline Status & Belum & 67 & 100,0 \\
Perkawinan & menikah & & 1,5 \\
\hline Lamanya & 3 tahun & 1 & 82,1 \\
Bekerja & 4 tahun & 55 & 16,4 \\
& $>5$ tahun & 11 & \\
\hline
\end{tabular}

Berdasarkan Tabel 1 dapat diketahui dari 67 responden, bahwa usia responden didominasi oleh usia yang berkisar 18 - 23 tahun berjumlah 51 responden $(76,1 \%)$, dengan jenis kelamin dari responden didominasi oleh laki-laki (45 orang, $67,2 \%$ ). Untuk status perkawinan, 100 orang responden belum menikah (100\%) dengan rata-rata dari responden yang sudah berwirausaha selama 4 tahun (55 responden, 82,1\%).

\section{Uji Validitas dan Uji Reliabilitas}

Penelitian ini menggunakan data primer yaitu berupa kuesioner atau daftar pertanyaan yang diberikan kepada responden yaitu wirausahawan mahasiswa dan kuesioner yang digunakan merupakan kuesioner yang disaurkan dari bahasa Inggris, sehingga perlu dilakukan pengujian atas instrumen pengumpulan data tersebut. Uji kualitas instrumen adalah sebagai berikut:

\section{Uji Validitas}

Uji ini dilakukan untuk mengukur sah atau tidaknya suatu kuisioner. Suatu kuisioner dikatakan valid jika pertanyaan pada kuisioner mampu untuk mengungkapkan sesuatu yang akan diukur oleh kuisioner tersebut. Uji validitas menunjukkan keadaan sebenarnya dan mengarah pada kes- 
esuaian alat ukur (Neuman, 2000). Uji validitas dapat dilakukan dengan menggunakan uji Comfirmatory Factor Analysis (CFA) adalah untuk mengetahui apakah indikator betul-betul merupakan bagian dari indikator konstruk tersebut. Analisis faktor akan mengelompokkan masing-masing indikator kedalam beberapa faktor. Jika suatu indikator merupakan indikator konstruk maka dengan sendirinya akan mengelompok menjadi satu dengan faktor loading yang tinggi. Nilai rule of thumb yang digunakan untuk CFA harus $>0,40$ (Hair et al., 2006).

\section{Uji Reliabilitas}

Uji reliabilitas dilakukan untuk memastikan instrumen tersebut merupakan alat ukur yang akurat dan dapat dipercaya.Uji reliabilitas menunjukkan sejauh mana sesuatu hasil pengukuran terhadap aspek yang sama atau disebut juga dengan interval concistency reliability. Pada penelitian ini, uji reliabilitas alat ukur yang digunakan adalah dengan menggunakan cronbach alpha. Pedoman yang digunakan untuk mengetahui tingkat reliabilitas dilihat dari besarnya cronbach alpha yaitu nilai cronbach alpha $>0,7$ meskipun 0,6 masih dapat diterima (Hair et al., 2006).

Hasil pengujian validitas dan reliabilitas untuk setiap variabel dapat dilihat pada Tabel 2.

Berdasarkan Tabel 2, dapat dijelaskan bahwa faktor yang pertama terdiri dari 5 item yang berhubungan dengan need for achievement, dengan muatan faktor antara 0,86 - 0,92. Oleh karena itu faktor 1 dinamakan dengan variabel need for achievement. Faktor 2 terdiri dari 5 item yang berhubungan dengan self-efficacy, dengan muatan faktor $0,70-0,91$. Varibel ini dinamakan dengan

Tabel 2

Validitas Indikator Variabel Bebas

\begin{tabular}{|c|c|c|c|c|c|}
\hline \multirow[b]{2}{*}{ Item Pertanyaan variabel independen } & \multicolumn{4}{|c|}{ Component } & \multirow[b]{2}{*}{5} \\
\hline & 1 & 2 & 3 & 4 & \\
\hline \multicolumn{6}{|l|}{$\mathrm{X} 1:$ Need for achievement (NA) } \\
\hline NA 5 & 0,92 & & & & \\
\hline NA 3 & 0,92 & & & & \\
\hline NA 2 & 0,92 & & & & \\
\hline NA 1 & 0,89 & & & & \\
\hline NA 4 & 0,86 & & & & \\
\hline Reliability & 0,97 & & & & \\
\hline \multicolumn{6}{|l|}{ X3: Self Efficacy (SE) } \\
\hline SE 4 & & 0,91 & & & \\
\hline SE 3 & & 0,80 & & & \\
\hline SE 2 & & 0,79 & & & \\
\hline SE 1 & & 0,72 & & & \\
\hline SE 5 & & 0,70 & & & \\
\hline Reliability & & 0,87 & & & \\
\hline \multicolumn{6}{|l|}{ X2: Locus of Control (LC) } \\
\hline LC 4 & & & 0,83 & & \\
\hline LC 3 & & & 0,69 & & \\
\hline LC 5 & & & 0,60 & & \\
\hline Reliability & & & 0,74 & & \\
\hline \multicolumn{6}{|l|}{ X5: Subjective Norm (SN) } \\
\hline SN 4 & & & & 0,73 & \\
\hline SN 3 & & & & 0,61 & \\
\hline SN 5 & & & & 0,60 & \\
\hline Reliability & & & & 0,64 & \\
\hline \multicolumn{6}{|l|}{ X4: Instrumental Readiness (IR) } \\
\hline IR 2 & & & & & 0,86 \\
\hline IR 1 & & & & & 0,50 \\
\hline Reliability & & & & & 0,60 \\
\hline Initial Eigenvalue & 5,65 & 4,87 & 2,68 & 2,17 & 1,42 \\
\hline Percentage of Variance Explained & 25,67 & 22,11 & 12,19 & 9,87 & 6,45 \\
\hline Cumulative Percentage of Variance Explained & 25,67 & 47,78 & 59,97 & 69,84 & 76,29 \\
\hline
\end{tabular}


variabel Self Efficacy.

Faktor tiga memiliki tiga item yang mengandung pertanyaan tentang locus of control dengan muatan faktor $0,69-0,83$. Oleh karena itu faktor tiga dinamakan dengan faktor locus of control. Faktor empat memuat tiga pertanyaan yang berhubungan dengan subjective norm, dengan muatan faktor $0,60-0,73$. Oleh karena faktor 4 dinamakan dengan faktor subjective norm. Faktor lima memuat pertanyaan yang berhubungan dengan instrumental readiness dengan muatan faktor 0,50 - 0,86. Oleh karena itu faktor lima dinamakan dengan faktor instrumental readiness.

Tabel di atas juga menunjukkan bahwa ke lima faktor yang didapatkan ari hasil analisis faktor, memiliki nilai Cronbach's alpha $>0,50$. Oleh karena itu untuk variabel bebas, yaitu locus of control, need for achievement, self efficacy, subjective norm dan instrumental readiness dapat dinyatakan bahwa kuesioner yang telah disusun untuk ke lima variabel tersebut adalah akurat dan andal.

Analisis faktor untuk variabel minat berwirausaha yang terdiri dari empat item pertanyaan yang berisikan tentang pemilihan karir sebagai wirausahawan juga dilakukan dan hanya menghasilkan satu variabel dengan nilai Cronbach alphanya 0,76 . Sedangkan analisis faktor untuk kesuksesan wirausaha mahasiswa juga menghasilkan satu faktor dengan Cronbach's alpha 0,99.

Berdasarkan hasil dari uji validitas dan reliabilitas di atas, maka dapat disimpulkan bahwa instrumen yang digunakan adalah valid dan reliabel sehingga dapat digunakan lebih lanjut untuk melakukan proses pengujian lebih lanjut dengan menggunakan hierarchical regression dalam rangka menguji aspek mediasi dari minat berwirausaha.

\section{Analisis Faktor-Faktor yang Mempengaruhi Minat Berwirausaha}

Minat berwirausaha dipengaruhi oleh variabel need for achievement, locus of control, subjective norm, instrumental readiness dan self efficacy, . Hal ini dibuktikan dengan penggunaan analisis regresi yang digunakan untuk menguji pengaruh kelima variabel tersebut terhadap minat berwirausaha. Berdasarkan hasil estimasi terhadap variabel yang diteliti melalui bantuan komputer dengan program SPSS, maka diperoleh seperti pada Table 3 di bawah ini :

Tabel 3

Hasil Analisis Regresi Linear Berganda Faktor-Faktor yang Mempengaruhi Minat Berwirausaha di KalanganMahasiswa di Provinsi Aceh

\begin{tabular}{cccc}
\hline Variabel & Koefisien & $\mathbf{T}_{\text {hitung }}$ & Sig \\
\hline Constant & 0,653 & 1,918 & 0,058 \\
X $_{1}$ & 0,345 & 3,049 & 0,003 \\
X $_{2}$ & 0,257 & 2,758 & 0.007 \\
X $_{3}$ & 0,262 & 2,587 & 0,011 \\
$X_{4}$ & 0,202 & 2,678 & 0,032 \\
$X_{5}$ & 0,266 & 2,742 & 0,024 \\
\hline
\end{tabular}

$\mathrm{DF}=100-3-1=96$

$R=0,784$

$\mathrm{R}^{2}=0,615$

Adjusted $\left(R^{2}\right)=0,603$

$\mathrm{t}_{\text {tabel }(0,05)}=1,980$

$\mathrm{F}_{\text {hitung }}=51,051$

$\mathrm{F}_{\text {tabel }}^{\text {hitung }}=2,70$

Berdasarkan hasil pengolahan data menunjukkan nilai konstanta 0,653 , need for avhievement $\left(\mathrm{X}_{1}\right) 0,345$, locus of control $\left(\mathrm{X}_{2}\right) 0,257$, dan self efficacy $\left(\mathrm{X}_{3}\right) 0,262$, instrumental readiness $\left(\mathrm{X}_{4}\right)$ 0,202, dan subjective norm $\left(\mathrm{X}_{5}\right)$ 0,266. Dengan nilai signifikansinya untuk semua variabel dibawah 0.05 .

Untuk mengetahui ada tidaknya hubungan antara variabel Need for Achievement $\left(X_{)}\right)$, Locus of Control $\left(X_{2}\right)$, dan Self Efficacy $\left(X_{3}\right)$ instrumental readiness $\left(\mathrm{X}_{4}\right)$ dan subjective norm $\left(\mathrm{X}_{5}\right)$ terhadap minat berwirausaha (Y), dapat dilihat dari koefisien korelasi (r). dari pengolahan data penelitian diperoleh korelasi (r) sebesar 0,784, ini berarti bahwa hubungan antara variabel Need for Achievement $\left(X_{1}\right)$, Locus of Control $\left(X_{2}\right)$, Self Efficacy $\left(X_{3}\right)$, instrumental readiness $\left(\mathrm{X}_{4}\right)$ dan subjective norm $\left(\mathrm{X}_{5}\right)$ terhadap minat berwirausaha (Y) adalah sebesar 78,4\%.

Dari hasil penelitian tersebut dapat disimpulkan bahwa untuk variabel bebas yang terdiri dari need for achievement, locus of control, self efficacy, instrumental readiness dan subjective norm mempengaruhi minat berwirausaha di kalangan mahasiswa di Provinsi Aceh. Sehingga faktor-faktor tersebut dapat dijadikan sebagai dasar dalam mendorong mahasiswa yang untuk berwirausaha sehingga mereka dapat membuka lapangan kerja bukan hanya untuk mereka sendiri tetapi juga bagi masyarakat luas. 


\section{REFERENSI}

Anoraga, Panji (2000). Menajemen Bisnis, Rineka Cipta, Jakarta.

Anoraga, Panji dan Djoko Sudantoko (2002). Koperasi, Kewirausahaan dan Usaha Kecil, Rineka Cipta, Jakarta.

Arikunto, Suharsimi (2000), Prosedur Penelitian Suatu Pendekatan Praktek, Edisi Revisi IV, Cetakan ke II, PT. Rineka Cipta, Jakarta.

Arikunto, S (2002). Prosudur penenelitian, Suatu pendekatan Praktek, Edisi Revisi V, Rineka Cipta, Jakarta.

Bandura, A (1986). Social Fondations of Thought and Action, Prentice-Hall, Englewood Cliffs, NJ.

Bratomo, S (2010). Locus of Control Dalam Sukses dan Gagal. http:/www.portalhr.com/kolom/2id47.html, akses 1 mei 2010

Boone, E. Louis \& David L. Kurtz (2002). Pengantar Bisnis Jilid 2, Erlangga Jakarta.

Ghozali, Imam (2005). Analisis Multivariete dengan Program SPSS, UNDIP, Semarang.

Hair, at al., (2006). Data Multivariate Analysis, edisi 6, Upper Saddle River: Printice Hall.

Haruman, Tendi Dkk (2008). Faktor-Faktor yang Mempengaruhui Kualitas Kewirausahaan Mahasiswa, Fakultas Ekonomi Widyatama.Bandung.

Hartono (1996). Kamus Paktis Bahasa Indonesia, Rinaka Cipta, Jakarta

Hisrich,R.J, Peters,M.P (2002). Entrepreneurship, NJ: McGraw-Hill.

http://dayuapoji.wordpress.com/07juni2008/workshop-bank-mandiri-perekonomian-indonesia-danentrepreneurship/

http://kutaraja uncategorized.com/rabu,26 november 2008 /studi faktor-faktor minat dan bakat dikalangan mahasiswa/.

Indriantoro, Nur dan Bambang Supomo, (2002). Metelogi Penelitian Bisnis Untuk Akuntansi dan Manajemen, Edisi Pertama, BPFE. Yokyakarta.

Jalaluddin Rakhmat (1995), Metode Penelitian Komunikasi, P.T. Remaja Rosdakarya, Bandung.

Kerlinger, Fred N., \& Elazar J. Pedhazur, (1987), Korelasi dan Analisa Regresi Ganda, Nur Cahaya, Yogyakarta

McClelland, D (1961). The Achievening Society, Princeton,New Jersey: Nostrand 
Mahdi Nur Hasan (2007). Faktor-Faktor Yang Mempengaruhi Minat Perilaku Konsumen Terhadap Minat Membaca Harian Waspada Di Kota Lhokseumawe (skripsi, tidak dipublukasiakan), Fakultas Ekonomi Universitas Malikussaleh.

Neuman, W. Laurence (2000). Social Research Methods: Qualitative and Quantitative Approach, A Person Education Company.

Purmiati, Atik (2004). Studi Tentang Faktor-Faktor Yang Mempengaruhi Minat Mahasisiwa Untuk Berwira Usaha (Studi Kasus Mahasiswa UNAIR Surabaya), Faculty of Ekonomic Airlangga University.

Ramayah, T dan Harun (2005). Entrepreneurial Intention Among The Student Of University Sains Malaysia (USM), Intenasional Journal Of Management and Entrepneurship. 1 (1) : 8-20.

Setiono, Agus (2006). Kewirausahaan, CV.Rineka cipta, Jakarta.

Sugiarto, S.D (2002). Metode Statistika Untuk Bisnis Dan Ekonomi, Ekonomi Cetakan Kedua, PT. Gramedia Pustaka Utama, Jakarta.

Sugiyono (2004). Metode Penelitian Bisnis, Cetakan Ketujuh, CV. Alfabeta, Jawa Barat

Sugiono, (2001), Statistik Non Parametris Untuk Penelitian, CV. Alfabeta, Jakarta

Sutarno, (2003). Perpustakaan dan Masyarakat, Yayasan Obor Indonesia, Ladang Pustaka dan Intermedia Jakarta.

Suryana (2003). Pedoman Praktis, Kiat Dan Proses Menuju Sukses, Selemba Empat, Jakarta.

Souitaris, V, Stetania Zerbinati, dan Andreas Al-Laham (2006). do Entrepneurship Progammes Raise Entrepreneurial Intention Of Scence and Engineering Student? The Effect Of Learning, Inspiration Andre Sources. Journal Of Business Venturing 22:566-591.

Steinhoff, Burgess (1993). Entrepreneurship and Commercial, (terjemahan), PT. Erlangga. Jakarta

Syahruddin (1998). Pengantar Kewirausahaan, PT,Sinar baru, Bandung.

Tanti (2008). Pengaruh Perceived Value dan Kepuasan pada Loyalitas Pelanggan di Moderasi oleh Variety Seeking (Tesis). Universitas Gajah Mada, Yogyakarta.

Utomo, (2002), (Online), (http://digilib.petra.ac.id/viewer.php?page=1\&submit. $x=0$ \&submit.y=0\&qual=high\&fname=/jiunkpe/s1/ikom/2007/jiunkpe-ns-s1-2007-51401113-4942-garden_palace-chapter3.pdf, diakses 3 Mei 2009).

Winarto (2003). Kewirausahaan, STIE-Indonesia, Jakarta.

Wulansari,Retno (2001), Goal Orientation, Self efficacy, dan Prestasi Belajar Pada siswa Peserta dan Non Peserta Program Pengajaran Intensif di Sekolah (Tesis). Jakarta 
Zimmerer, W. Thomas (1993). Entrepreneurship and The New Vanture Formation, (terjemahan), PT.Erlangga, Jakarta.

Zimmerer, T.W, Scarborough, N.M (2002). Essentials of Entrepreneurship and Small Bussiness Management, $N J$ : Person Education. 